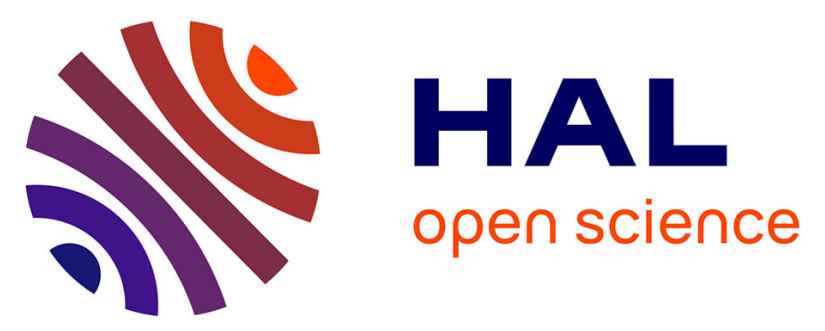

\title{
Comparison of resistance against erythromycin and moxifloxacin, presence of binary toxin gene and PCR ribotypes in isolates from 1990 and 2008
}

\author{
C. Ilchmann, N. H. Zaiss, A. Speicher, M. Christner, G. Ackermann, H. Rohde
}

\section{- To cite this version:}

C. Ilchmann, N. H. Zaiss, A. Speicher, M. Christner, G. Ackermann, et al.. Comparison of resistance against erythromycin and moxifloxacin, presence of binary toxin gene and PCR ribotypes in isolates from 1990 and 2008. European Journal of Clinical Microbiology and Infectious Diseases, 2010, 29 (12), pp.1571-1573. 10.1007/s10096-010-1017-9 . hal-00608813

\section{HAL Id: hal-00608813 https://hal.science/hal-00608813}

Submitted on 15 Jul 2011

HAL is a multi-disciplinary open access archive for the deposit and dissemination of scientific research documents, whether they are published or not. The documents may come from teaching and research institutions in France or abroad, or from public or private research centers.
L'archive ouverte pluridisciplinaire HAL, est destinée au dépôt et à la diffusion de documents scientifiques de niveau recherche, publiés ou non, émanant des établissements d'enseignement et de recherche français ou étrangers, des laboratoires publics ou privés. 
Diseases

Editorial Manager(tm) for European Journal of Clinical Microbiology \& Infectious

Manuscript Draft

Manuscript Number: EJCMID-D-09-00556R2

Title: Comparison of resistance against erythromycin and moxifloxacin, presence of binary toxin gene and PCR ribotypes in Clostridium difficile isolates from 1990 and 2008

Article Type: Brief Report

Keywords: Clostridium difficile; PCR ribotype; resistance; epidemiology; binary toxin

Corresponding Author: Dr. Corina Ilchmann,

Corresponding Author's Institution: Universitätsklinikum Hamburg-Eppendorf

First Author: Corina Ilchmann

Order of Authors: Corina Ilchmann; Angelika Speicher; Nils H Zaiß; Grit Ackermann; Holger Rohde; Martin Christner

Abstract: World wide increasing rates of Clostridium difficile infections (CDI) with severe courses and outbreaks have been reported. This change in CDI epidemiology has on one hand been related to the spread of specific PCR ribotypes (e.g. 027) and on the other hand to increased prevalence of resistant C. difficile strains. This single centre retrospective analysis characterized resistance against erythromycin and moxifloxacin, presence of binary toxin gene and ribotypes in $73 \mathrm{C}$. difficile isolates from 2008 in comparison with 23 isolates from 1990. In 1990 five different PCR ribotypes including 027 were identified. Resistance against erythromycin was detected in 3 / 23 (13\%), while 20 / 23 (87\%) of all isolates were susceptible to both, erythromycin and moxifloxacin. In contrast, in 2008 a significantly increased prevalence of resistant C. difficile strains was observed, with 40 / 73 (54.8 \%) isolates being resistant against both antibiotics. Resistant C. difficile strains were mainly assigned to PCR ribotype 001. No isolates belonging to PCR ribotype 027 were identified. Our data provide evidence that increase of resistant $\mathrm{C}$. difficile strains belonging to PCR ribotype 001 rather than the spread of $\mathrm{C}$. difficile PCR ribotype 027 contribute to the changing epidemiology of CDI. 
C. Ilchmann et al., EJCMID-D-09-00556R1 revised

1 Comparison of resistance against erythromycin and moxifloxacin, presence of binary

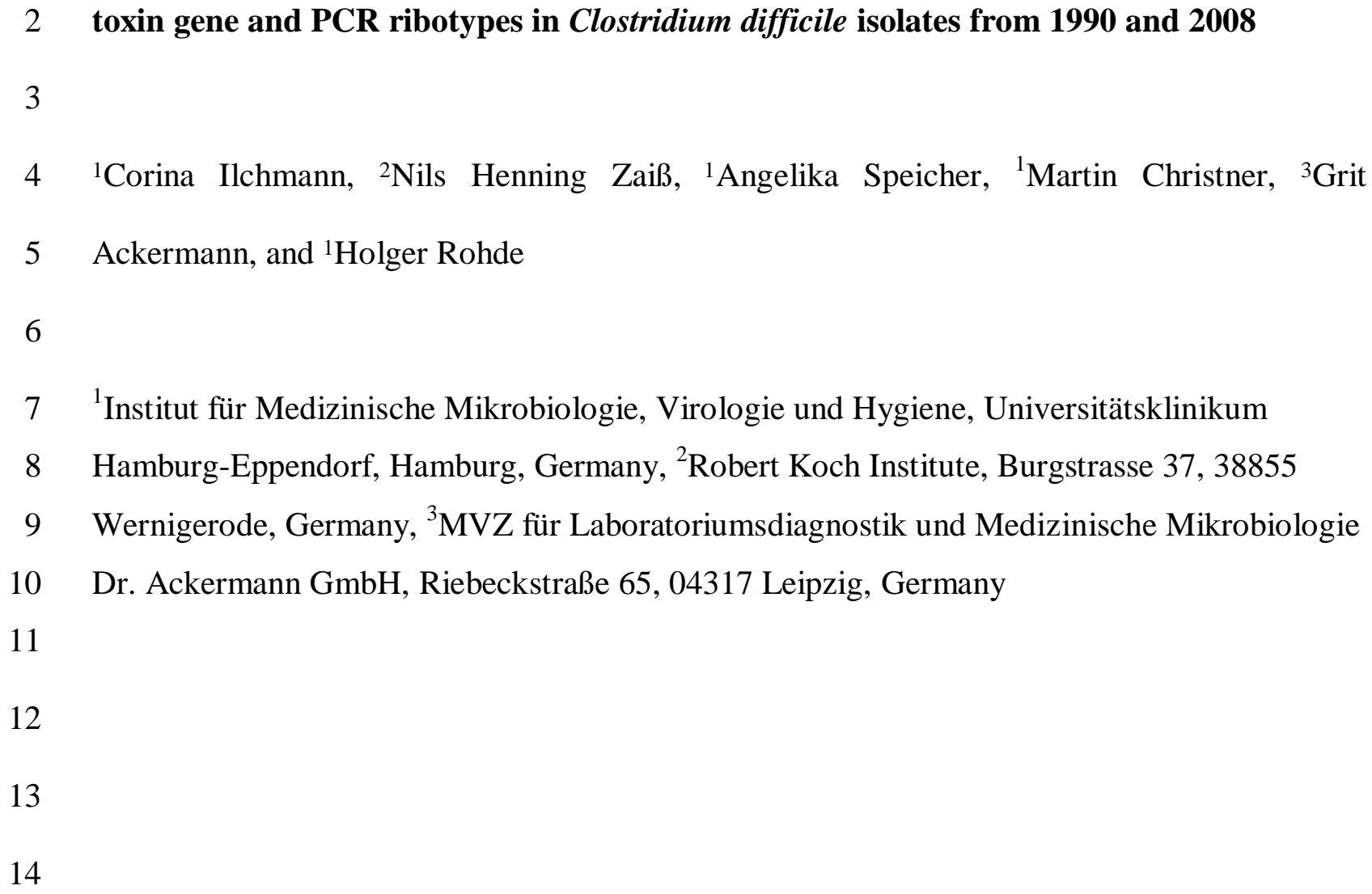


C. Ilchmann et al., EJCMID-D-09-00556R1 revised

\section{Abstract}

2 World wide increasing rates of Clostridium difficile infections (CDI) with severe courses and

3 outbreaks have been reported. This change in CDI epidemiology has on one hand been related

4 to the spread of specific PCR ribotypes (e.g. 027) and on the other hand to increased

5 prevalence of resistant $C$. difficile strains. This single centre retrospective analysis

6 characterized resistance against erythromycin and moxifloxacin, presence of binary toxin

7 gene and ribotypes in 73 C. difficile isolates from 2008 in comparison with 23 isolates from

8 1990. In 1990 five different PCR ribotypes including 027 were identified. Resistance against

9 erythromycin was detected in $3 / 23(13 \%)$, while $20 / 23(87 \%)$ of all isolates were

10 susceptible to both, erythromycin and moxifloxacin. In contrast, in 2008 a significantly

11 increased prevalence of resistant $C$. difficile strains was observed, with $40 / 73$ (54.8\%)

12 isolates being resistant against both antibiotics. Resistant $C$. difficile strains were mainly 13 assigned to PCR ribotype 001. No isolates belonging to PCR ribotype 027 were identified. 14 Our data provide evidence that increase of resistant $C$. difficile strains belonging to PCR 15 ribotype 001 rather than the spread of $C$. difficile PCR ribotype 027 contribute to the changing 16 epidemiology of CDI.

17

18 Key words: Clostridium difficile, PCR ribotype, resistance, binary toxin 
C. Ilchmann et al., EJCMID-D-09-00556R1 revised

1 Clostridium difficile has long been considered a significant causative agent of nosocomially

2 acquired diarrhoea [1]. Since 2002 increasing numbers of infections, outbreaks and severe

3 cases of Clostridium difficile-infections (CDI) have been reported. In part, these infections

4 were attributed to variant $C$. difficile strain belonging to PCR ribotype 027 [1]. This strain

5 produces binary toxin CDT, encoded by $c d t A$ and $c d t B$, and has a partial deletion of the

6 regulatory $t c d C$ gene, resulting in toxin $\mathrm{A}$ and $\mathrm{B}$ hyperproduction [2]. In addition,

7 independent PCR ribotypes (e.g. 001, 053, 078 and 106) can cause outbreaks and severe

8 courses of $C$. difficile infections [3], indicating that currently epidemiology of virulent $C$.

9 difficile strains is subject to complex changes that cannot solely be attributed to the spread of

11 We here analyzed $C$. difficile isolates from patients hospitalized at the University Hospital

12 Centre Hamburg-Eppendorf in $1990(n=23)$ and $2008(n=73)$ with clinical suspicion of CDI.

13 Isolates from 1990 were randomly collected over the whole year. These stool samples were 14 not tested for the presence of toxin A or B. No information about antibiotic therapies was 
C. Ilchmann et al., EJCMID-D-09-00556R1 revised

1 ribotypes were determined. Most isolates (44/73; 60.3\%) were assigned to ribotype 001, 25

2 isolates belonged to sporadic ribotypes $(003, n=3 ; 010, n=1 ; 012, n=1 ; 014, n=8 ; 015, n=1$;

$3020, \mathrm{n}=1 ; 023, \mathrm{n}=1 ; 032, \mathrm{n}=1 ; 042, \mathrm{n}=1 ; 045, \mathrm{n}=1,046 ; \mathrm{n}=1 ; 066, \mathrm{n}=1 ; 078, \mathrm{n}=1 ; 081, \mathrm{n}=2 ;$

$4087, \mathrm{n}=1)$. Four strains were not typeable, PCR ribotype 027 was not detected. $c d t B$ was

5 found in only $3 / 73(4.1 \%)$ isolates belonging to PCR ribotypes 023, 066, and 078,

6 respectively. Statistical analysis revealed that $c d t B$ prevalences in 1990 and 2008 did not

7 differ significantly ( $\mathrm{p}=0.590$, Fisher's exact test). However, compared to $C$. difficile isolates

8 from 1990, C. difficile isolates from 2008 exhibited increased MICs against erythromycin

$9 \quad$ MIC $_{50}: 256 \mu \mathrm{g} / \mathrm{ml}$ vs. $1.5 \mu \mathrm{g} / \mathrm{ml}$; $\mathrm{MIC}_{90}: 256 \mu \mathrm{g} / \mathrm{ml}$ vs. $\left.32 \mu \mathrm{g} / \mathrm{ml}\right)$ and moxifloxacin $\left(\mathrm{MIC}_{50}\right.$ : $32 \mu \mathrm{g} / \mathrm{ml}$ vs. $0.75 \mu \mathrm{g} / \mathrm{ml}$; $\mathrm{MIC}_{90}: 32 \mu \mathrm{g} / \mathrm{ml}$ vs. $\left.1 \mu \mathrm{g} / \mathrm{ml}\right) .40 / 73(54.8 \%)$ of the isolates from 2008 were resistant against erythromycin and moxifloxacin, an isolated resistance against erythromycin was detected in $4 / 73(5.5 \%)$ isolates and against moxifloxacin in $2 / 73(2.7$ $\%$ ) isolates (Table 1). Overall, compared with $C$ difficile strains from 1990 the proportion of erythromycin and moxifloxacin susceptible strains was significantly lower in C.difficile isolates from 2008 (20/23, $87 \%$ vs. 27/73, $37 \%$, p<0.001). Importantly, 37 / 44 (84.1\%) isolates belonging to PCR ribotype 001, but only 2 / 29 (6.9\%) strains belonging to PCR ribotypes other then 001 were resistant against erythromycin and moxifloxacin. All $c d t B$ positive isolates from 2008 were susceptible against both agents.

Epidemiological evidence suggest that on one hand occurrence and spread of variant $C$. difficile PCR ribotype 027 contributed to the ever increasing number of CDI cases in regions with epidemic outbreakes [1]. However, spread of this strain is clearly not the exclusive reason for the changing epidemiology and clinical presentation of CDI in general. The low prevalence of ribotype 027 found in our study is in line with a study investigating the distribution of PCR ribotypes in a European collection of 411 C. difficile isolates, assigning only $6,2 \%$ of all isolates to PCR ribotype 027 [5]. In southern Germany CDI was predominantly caused by $C$. difficile belonging to ribotype 001 [6]. In line with this study we 
C. Ilchmann et al., EJCMID-D-09-00556R1 revised

1 here document the importance of PCR ribotype 001 in our hospital, and it is tempting to

2 speculate that ribotype 001 is of special importance in Germany [7].

3 Interestingly, we were able to demonstrate presence of $c d t B$-positive $C$. difficile ribotype 027

4 isolates already in a collection of 23 strains from 1990, demonstrating that ancestors of the

5 current epidemic clone were present in virulent $C$. difficile populations almost 20 years ago.

6 Detailed molecular comparison of these early strains with current $C$. difficile 027 isolates

7 could provide new insights into the evolution of this particular strain, which is a prerequisite

8 for understanding the molecular basis for its epidemic potential.

9 It is well accepted that antibiotic treatment is a major risk factor for $C$. difficile gut colonization, infection and the subsequent development of CDI [1]. We here document a

11 significantly increased prevalence of erythromycin and moxifloxacin resistant $C$. difficile

12 isolates between 1990 and 2008. It should be emphasized that it cannot be excluded that this 13 finding results from differences between patients groups sampled in 1990 and 2008, rather 14 than differences between $C$. difficile populations. In addition, the results could be biased by 15 the different length of periods used for sampling. However, as especially fluoroquinolones 16 have more recently been identified as an important risk factor for the development of CDI [8], 17 it is reasonable to speculate that a host environment significantly exposed against 18 fluoroquinolones favours the expansion of resistant $C$. difficile clones [9]. Indeed, several 19 other studies lend support to this idea [10], demonstrating that significant proportions of 20 clinical $C$. difficile isolates from different PCR ribotypes are resistant against 21 fluoroquinolones. Strikingly, in our collection erythromycin and fluoroquinolone resistance 22 was associated with isolates belonging to PCR ribotype 001, suggesting that the over all 23 increase of erythromycin and moxifloxacin resistant $C$. difficile isolates is in part related to 24 the spread of this ribotype. The multi resistant phenotype of $C$. difficile PCR ribotype 001 25 could, in addition to its ability to sporulate more frequently [11], explain the particular 26 epidemic potential of this strain. 
C. Ilchmann et al., EJCMID-D-09-00556R1 revised

\section{Acknowledgements}

2 The authors thank Wolfgang Witte for critically reading the paper. There was no financial

3 support for the study. All authors state that there are no potential conflicts of interest.

\section{References}

1. Rupnik M, Wilcox MH, Gerding DN (2009) Clostridium difficile infection: new developments in epidemiology and pathogenesis Nat Rev Microbiol 7:526-536.

2. Kuijper EJ, Coignard B, Tull P (2006) Emergence of Clostridium difficile-associated disease in North America and Europe Clin Microbiol Infect 12 Suppl 6:2-18.:2-18.

3. Rupnik M, Widmer A, Zimmermann O, Eckert C, Barbut F (2008) Clostridium difficile toxinotype V, ribotype 078, in animals and humans J Clin Microbiol 46:2146.

4. Bidet P, Barbut F, Lalande V, Burghoffer B, Petit JC (1999) Development of a new PCR-ribotyping method for Clostridium difficile based on ribosomal RNA gene sequencing FEMS Microbiol Lett 175:261-266.

5. Barbut F, Mastrantonio P, Delmee M, Brazier J, Kuijper E, Poxton I (2007) Prospective study of Clostridium difficile infections in Europe with phenotypic and genotypic characterisation of the isolates Clin Microbiol Infect 13:1048-1057.

6. Borgmann S, Kist M, Jakobiak T, Reil M, Scholz E, von Eichel-Streiber C, Gruber H, Brazier JS, Schulte B (2008) Increased number of Clostridium difficile infections and prevalence of Clostridium difficile PCR ribotype 001 in southern Germany Euro Surveill 13:19057. 
C. Ilchmann et al., EJCMID-D-09-00556R1 revised

1

2

3

4

7. Arvand M, Hauri AM, Zaiss NH, Witte W, Bettge-Weller G (2009) Clostridium difficile ribotypes 001, 017, and 027 are associated with lethal $C$. difficile infection in Hesse, Germany Euro Surveill 14:19403.

8. McDonald LC, Killgore GE, Thompson A, Owens RC, Jr., Kazakova SV, Sambol SP, Johnson S, Gerding DN (2005) An epidemic, toxin gene-variant strain of Clostridium difficile N Engl J Med 353:2433-2441.

9. Coia JE (2009) What is the role of antimicrobial resistance in the new epidemic of Clostridium difficile? Int J Antimicrob Agents 33 Suppl 1:S9-12.:S9-12.

12 11. Fawley WN, Underwood S, Freeman J, Baines SD, Saxton K, Stephenson K, Owens 13 RC, Jr., Wilcox MH (2007) Efficacy of hospital cleaning agents and germicides 14 against epidemic Clostridium difficile strains Infect Control Hosp Epidemiol 28:92015925. 
Table 1: Distribution of erythromycin and moxifloxacin MIC values in C. difficile isolates from 1990 and 2008

\begin{tabular}{|c|c|c|c|c|c|c|c|c|c|c|c|c|c|}
\hline \multirow{2}{*}{$\begin{array}{l}\text { Antimicrobial } \\
\text { agent (year) }\end{array}$} & \multicolumn{12}{|c|}{ No. of strains for which the antimicrobial agent MIC $(\mu \mathrm{g} / \mathrm{ml})$ was* } & \multirow[t]{2}{*}{$\begin{array}{c}\text { Geometric } \\
\text { mean }(\mu \mathrm{g} / \mathrm{ml})\end{array}$} \\
\hline & 0,125 & 0,25 & 0,5 & 0,75 & 1 & 1,5 & 2 & 4 & 8 & 16 & 32 & 256 & \\
\hline ERY (1990) & & 2 & 1 & 3 & 2 & 8 & 4 & & & & 1 & 2 & 24.75 \\
\hline ERY (2008) & 2 & & 2 & 3 & 7 & 15 & 1 & & & & & 43 & 151.27 \\
\hline MX (1990) & & & 6 & 9 & 8 & & & & & & & & 0.77 \\
\hline MX (2008) & & & 14 & 11 & 7 & & & & & & 41 & & 18.28 \\
\hline
\end{tabular}

* Breakpoints used to differentiate susceptible and resistant isolates were defined for ERY at $\geq 4 \mu \mathrm{g} / \mathrm{ml}$ (according to DIN) and for MX at $\geq 8 \mu \mathrm{g} / \mathrm{ml}$ (according to CLSI) 


\section{Reviewer 1}

1. This is a very short five page long paper with very few data. Only one table with original data is given (table 1) whereas the MIC of table 2 can be directly calculated from the original data in table 1.

Table 2 was removed, geometric means were included in table 1.

2. The authors try to demonstrate "epidemiologic changes", however, this is not possible due to limitations of the study design. Therefore, the present characterisation of these ad hoc collected $C$. difficile isolates is certainly of interest for the local situation but to very less extent to the scientific community.

We have removed the respective sentence.

\section{General comments}

At the end of the manuscript it should clearly stated. The results of the present study are limited due to several reasons......

In order to fit with the requirements for a brief report we saw no possibility to add the statement. However; the limitation referee 1 is referring to are mentioned in the text (page 5, line 12 ff:" It should be emphasized that it cannot be excluded that this finding results from differences between patients groups sampled in 1990 and 2008, rather than differences between $C$. difficile populations. In addition, the results could be biased by the different length of periods used for sampling.")

\section{Abstract line 6 please change "The present study" in "The present single center} retrospective analysis"

The sentence was changed accordingly.

2. line 14 please substitute: No isolates belonging to PCR ribotype 027 were identified "in our cohort".

Sentence was changed.

3. line 17 and other parts of the manuscript inclucing page 7 line 8: The term "epidemiology" should not be used throughout the complete manuscript in this retrospective analysis with unselected samples.

The term was, if referring to our observations, deleted.

4. page 6 lines 3-4: "variant C. difficile PCR ribotype 027 contributed to the ever increasing number of cases" please substitute "in regions with epidemic outbreakes" The sentence was changed.

5. page 6 line 14: "we here document the importance of PCR ribotype 001"please substitute "when analyzing the more recent isolates"

The sentence was modified accordingly.

6. Please add a comment into the discussion concerning differenced betwee the historical 027 strains detected in 1990 and the new epidemic outbreak strains. We have no detailed knowledge about these differences. However, we highlight the possibility to use isolates from 1990 for comparative analysis with recent outbreak strains (page 5, lien $3 \mathrm{ff}$ : Interestingly, we were able to demonstrate presence of $c d t B$-positive $C$. difficile ribotype 027 isolates already in a collection of 23 strains from 1990, demonstrating that ancestors of the current epidemic clone were present in virulent $C$. difficile populations 
almost 20 years ago. Detailed molecular comparison of these early strains with current $C$. difficile 027 isolates could provide new insights into the evolution of this particular strain, which is a prerequisite for understanding the molecular basis for its epidemic potential."

7. A direct comparison of antibiotic susceptibility and binary toxin between the 1990 and 2008 strains with the same ribotypes may be of interest

We agree with the referee. However, we think that due to the small numbers of certain ribotypes this analysis in our collection is not meaningful.

8. $\quad$ Page 6 line 22: "The rare occurrence of cdtB in our and independent $C$. difficile collections $[8,11]$ shows that the ability to produce binary toxin is of minor importance for increase of CDI rates," The study design is not appropriate to give a statement about the clinical importance of binary toxins. Only descriptive analysis is allowed.

To cope with this point of criticism we have changed the sentence, removing the statement related to our findings.

\section{Reviewer 2}

The term fluorquinolon was corrected throughout the text.

\section{Page 5, line 1.}

The authors should consider inserting the $87 \%$ proportion as stated in the abstract, to describe the number of isolates susceptibles to both clones. Otherwise, the $87 \%$ proportion cannot be found in the main text of the manuscript.

We followed the suggestion.page 3, line $24 \mathrm{ff}$ : “...... while 20 / 23 (87\%) were susceptible against moxifloxacin and erythromycin (Table 1).”)

Page 5, line 18

For the same reason as above, $87 \%$ should be mentioned again in this sentence, so that it is clear which are the two proportions that are being compared. A suggestion:

"Overall, compared with C difficile strains from 1990 the proportion of erythromycin and moxifloxacin susceptible strains was significantly lower in C.difficile isolates from 2008 (20/23, 87\% vs 27/73, 37\%, p<0.001).

We followed the suggestion. 